\title{
He was my son, not a dying baby
}

EDITOR'S

CHOICE

Correspondence to

Ms Pauline Thiele, C/O PO Box

298, Red Hill South VIC 3937,

Australia;

liam194@gmail.com

Received 22 February 2010

Accepted 27 August 2010

\section{Pauline Thiele}

Conversing happily with my son we had been driving home when my mobile phone rang. Startled at the sound of my obstetrician's voice I had pulled off to the side of the road. At 18 weeks gestation I was told in a factual tone that the results from my serum screen had come back, indicating that our baby was at increased risk of Trisomy 18. Gripping the steering wheel my head had spun as he talked, explaining that Trisomy 18 was worse than Trisomy 21 because our baby was not going to live. We had been thrilled when we heard the news of my pregnancy but now my temples throbbed and tears brimmed in my eyes. Suddenly my world was turned upside down and it had felt like someone reached into my chest and ripped my heart out.

My husband and I decided that an amniocentesis was needed for a positive diagnosis and this was arranged for the following day. Studiously the sonographer performed the diagnostic ultrasound with a furrow across his brow. Watching the monitor I saw my baby moving as I watched the colours of red and blue flow through the heart and heard the regular, fast rhythm of the heartbeat. Quietly I hoped that the news was good but the creased brow had told me otherwise. Holding the amniotic fluid in his right hand the sonographer had glanced from it to me and empathetically informed me that the news wasn't good and that he didn't need to send the sample off for a positive diagnosis. Once again my world was crashing and all I wanted to do was bury my head in a pillow and sob.

The following weekend dragged and had been filled with streams of tears and emotional turmoil. All I wanted to do was hold my unborn child in my arms and love and protect him or her. The aching in my heart refused to cease, as had the dull throbbing in my head. Through the tears, however, I had been able to gather my thoughts and weigh up what was best for our unborn child, as well as, for us as a family. At 18 weeks my baby already had a well developed central nervous system, certainly a beating heart, all organ systems were developing and the ultrasound had allowed me to see my baby's well defined features. However, the heart was enlarged and there was significant hydrocephalus and yet, day by day, I felt and welcomed the movements. Was termination an option and, if so, what were the consequences for our unborn child and for ourselves? Who could advise me? There were groups that were extreme but they lacked balance in their arguments and at this time it was not what I wanted or needed. At the end of the day the only person that was there to advise me was myself and I was torn because I didn't feel like I knew enough to make such decisions. The thought of destroying this much loved life through termination made my temples throb painfully and made me feel sick to the stomach. There was no way that I could entertain the idea of possibly chopping my baby into several different pieces through the use of a metal curette and cause him or her excruciating pain and, in the end, this thought was more powerful and influential than any emotional pain that I might have to endure. My heart told me that what was best for us all was to love this precious baby and give him or her every possible opportunity of life.

On the following Monday my obstetrician confirmed what we already knew but also that we were to have a son, who we would now name Liam. There was no discussion between the obstetrician and ourselves about a termination but when offered the choice we had informed him that we would continue as normal and no further discussion about Trisomy 18 or our choices were entered into. This was the way it was to be throughout my pregnancy, no advice was proffered; although on each visit I would be asked how I was coping. At each visit, when this question was asked I would answer, 'One day at a time'. The ensuing months encompassed shared-care visits between my obstetrician and general practitioner. Concerned about the stress that a vaginal delivery would place on Liam, knowing that Trisomy 18 babies were easily stressed, I had asked at one consultation about the possibility of a caesarean section but the obstetrician dismissed the idea without going into any great detail. He did, however, consent to the idea of monitoring Liam during delivery.

My only source of information about Trisomy 18 was to come from the internet, which was then supplied by myself to these professionals and I was to wonder, particularly, about my obstetrician's lack of initiative in gathering his own information and about his lack-lustre interest. Was it that he considered my son not to be worth the investment because, after all, he was going to die? Although, in the end it was my assumption that when you made a choice that went against the grain that this was what you got-no support! However, I knew that this was about my child and to me he was not just a dying baby, he was my son, and I knew that I would fight for his rights because I was his mother and his advocate.

As the months went by I ventured into the hospital where Liam was to be delivered to introduce myself and take in copies of the reports. When the midwife retrieved my file I was surprised to see that there were no copies of any results and only a few scrawled notes. However, I was relieved that the ward would now know; but my first shock was not to be my last shock! Still no support came from anywhere and because Liam also had spina bifida I knew that I needed some support and knowledge about the condition so went to where I had hoped that some support would come from-the internet. 
Finally my support came in the form of four developmental paediatricians in the USA and with a second response from three of these men and, realising my distress, they had offered to make the initial contact for me with the required professionals in Australia. Two of these wonderful men provided me with the information about caring for spina bifida and one of these two also told me what I could expect to see with Liam's Trisomy 18. With my head resting in my hands the tears flowed freely from a mixture of emotions: relief, sorrow, gratitude, anxiety, joy, excitement, anguish, elation and desolation.

Realising that I should have support, if not from obstetrics then at least from paediatrics, I once again drove to the hospital of delivery to ask about spina bifida and to take in the results of the second diagnostic ultrasound. There I was surprised to find that still no information had been provided to the ward by the previous midwife. Once again, I was to supply the required information on Trisomy 18. Did these professionals believe that I should have terminated, as some people suggested behind my back? Who were these people to disregard my son and what right did they have to do so? And who were they to be paternalistic in their beliefs that they knew what was best for me?

From here on was to become an even more emotionally intensive experience. Midweek I received a call informing me that the hospital would not allow Liam to be born there. Feeling angry I had wanted to cry but, instead, ventured into the director of obstetrics rooms to challenge his decision. Bluntly the director informed us that our son could not be born at the hospital because they did not have the necessary facilities for full resuscitation of a baby with Trisomy 18. With fire in my eyes I had defiantly, but quietly, informed him that we had never asked for any aggressive measures to be performed on Liam. Feeling like a mother bear fighting for her cub I told him that Liam already had cardiomegaly, pericardial effusion and significant hydrocephalus and no one would harm my son, and that included any forms of medical treatment that might cause him pain or distress but, rather, I explained that all we wanted was symptom relief so that he could die peacefully. Recognition flashed across his face and he voiced his consent and arranged for me to meet with the director of paediatrics the following day.

With butterflies in my stomach, and still ready for a fight, I had been welcomed into the paediatrician's office. But suddenly there was no need to fight anymore and a hand was held out, and that hand was pulling me in from the deep waters that I had been struggling to tread on my own. Finally, at 33 weeks gestation, I had unconditional support from this wonderful man. We spoke about Liam's care and I explained that if it was required I wanted morphine used for any cardiac pain, even though I knew it could cause respiratory depression. The paediatrician explained that he would support me in this choice but I needed to be aware that there would be some individuals who would accuse us of murder because of the use of morphine in a neonate, for the most part related to the respiratory depression. Angry at the thought of such an accusation I had defiantly told him that I would be prepared for such a confrontation. Gentleness tinged his voice as he told me that I could challenge these people but he didn't want me doing it at the point in time when my baby had just died.

To join the support from this paediatrician came the support of the director of palliative care. Yet, the support of these two men did not mean that the rollercoaster ride was over because the hospital's lawyer refused to allow Liam to be born there. United, these two wonderful doctors fought against the "powers that be,' but fight as they may we were left wondering where Liam would be born and if we would be allowed the support that we had finally found. Up until this time I had managed on my own, particularly as my husband did not cope well with the news that our son would die, but the fear of losing the support of both of these doctors, my only support, left me distraught and, once again, I wept.

At 36 weeks gestation I feared that Liam had stopped moving and remembering that the unit manager at a small, local hospital suggested that I could have his heart monitored if I ever had any such fears I had gone there. The midwife at this time talked abruptly to me and insisted that any monitoring was out of the question as they had no radiological support. Left bewildered and fearing for my son's life I drove into the hospital of delivery. It was here that a registrar performed a basic scan and swinging the monitor around for me to see had curtly said, 'See? No heart beat!' Stunned at her callousness I had been unable to say anything but had seen raw anger flash across my husband's face. However, a confirming diagnostic ultrasound done by an empathetic sonographer confirmed that Liam had died of multiple organ failure.

Liam's delivery the next day was quick and I was supported wonderfully by midwifery staff. At long last I was blessed to hold my tiny baby in my arms. Tenderly I held my son and whispered words of love to him and I knew that it had been worth everything just for this moment, just to hold my son in my arms. Shortly after delivery our paediatrician entered and holding Liam prone he had gently supported his head as we looked at his spina bifida. Sweeping his broad hand over the back he said, 'We could have fixed this up but we couldn't have done anything for what was going on inside of him'. He then took Liam and wrapped him securely in a soft blanket. Sitting on the edge of the bed the paediatrician tenderly held Liam in his arms and my heart swelled with love for my sweet baby and in gratitude to this man who gently patted my son on the bottom. Looking into my eyes the paediatrician softly commented, 'If a baby can know stress in utero then surely it can know love. Liam knew that he was loved!' If nothing else, this made the journey worth the ride, for my son to know that he was loved and for him to be protected and cradled safely within his mother.

In memory of Liam 19 April 2009; your Mummy will always love you.

To those who encouraged me to write about Liam's story, I thank you.

Competing interests None.

Patient consent Obtained.

Provenance and peer review Not commissioned; externally peer reviewed. 